\title{
THE EFFECT OF COVID-19 ON HEALTHCARE DOCTORS IN \\ TURKEY: THE CASE OF ISTANBUL CHAPA(ÇAPA) HOSPITAL
}

Mortaza CHA YCHI SEMSARI, PhD. C. (iD) $1 *$

Kerim KARADAL, PhD. C. (iD) 2

1 Istanbul University, Political Science and Public Administration, alimortezacaycisemsari@gmail.com *Correspondent Author.

2 Uludağ University, Institute of Social Sciences, Management and Organization, kerimkaradal@gmail.com

\section{Article history:}

Submission 28 February 2021

Revision 12 May 2021

Accepted 16 August 2021

Available online 31 August 2021

\section{Keywords:}

Covid-19,

Istanbul Chapa Hospital,

Social State,

Neoliberal Policies,

Doctors,

Global Health

DOI:

https://doi.org/10.32936/pssj.v5i2.256

\begin{abstract}
A b s t r a c t
After 1945, states began to be more effective on the economy. This situation showed itself under the name of Welfare State or Social State. However, neo-liberal policies were seen as a solution to the economic problems that started to be experienced from the beginning of the $1980 \mathrm{~s}$, and the Social State or Welfare State practices began to decline. Depending on the expansion of neo-liberal policies, states have withdrawn from many service areas in accordance with the free market understanding. One of these withdrawals is health services.

Health services have been transformed into free market conditions through privatization, and the health service that citizens benefit from has been transformed into paid. On the other hand, in line with neo-liberal policies, principles such as performance, contract and productivity have been introduced to healthcare workers.
\end{abstract}

Healthcare workers and especially doctors are at the forefront of the fight against Covid-19, which started in Wuhan, China and spread to the world. In order to eradicate the epidemic, doctors had to face the worsening working conditions (suspension of the rights to resign and ask for retirement, excessive patient care, etc.) while racing against time to save the patients. This situation brings with it many problems in working life for the doctors who are fighting the epidemic in Turkey as well as in the world.

In this study, the effect of the covid-19 epidemic in Turkey on the pandemic service of Istanbul University Istanbul Medical Faculty Chapa Hospital in the process leading to the liquidation of the social state was investigated.

\section{Introduction}

With the second half of the 20th century, it is seen that the intervention of states on the global economy has increased. States with economic interventions; focused on developing policies to increase the living standards of citizens with welfare state and social state practices. In this context, states develop a control mechanism in the market with welfare state and social state practices. One of the most important of these applications is the services provided by the state on the health system.
In the mid-1970s, both economic and political developments in the countries that faced the oil crisis due to the OPEC embargo in the world, and with the addition of the economic depression, neoliberal policies emerged with the practices they developed to get rid of the increasing costs. In this context, the criticism towards the state has increased and the future of the social state has begun to be discussed. In this direction, the first criticism of the welfare state came from the neoliberal understanding and it was underlined that the state should return to its old function, namely "night watchman", and that the economic field should be left to the market completely (Ataay, 2016). It is the financial 
problems seen in health as well as in other services that affect the restructuring of countries, especially in the field of health, which started in the late 1980s (Günaydın, 2011).

The beginning of the 1990s and the 2000s, together with the phenomenon of globalization, revealed the understanding that states can no longer do any other task than to control the market (Koçak, 2009; Kayan, 2015). The liquidation process of the social state, which started with neo-liberal policies, gained momentum with globalization. Today, health care in the world is shaped according to the market economy.

The Covid-19 epidemic, which started in Wuhan, China in 2019, has brought about discussions in the global arena on the provision of health services. With the Covid-19 epidemic, questions arise such as whether there is any loss of rights for health workers and what kind of problems it causes on health care providers. In this context, within the scope of the study, the effect of the Covid-19 epidemic in Turkey on the pandemic service of Istanbul University Istanbul Medical Faculty Chapa Hospital in the process leading to the liquidation of the social state in a globalized world was investigated.

\section{The Effect of Neo-Liberalism on Health}

\section{System in A Globalized World}

The 1970s were the years when the social state phenomenon was criticized. With the establishment of Thatcher government in England in 1979, the criticisms of the American President Reagan towards the welfare state have been an important support for neoliberalism, and since the beginning of the 1980s, international organizations such as the World Bank (WB) in developed countries and then in developing countries. It has also accelerated a global debate with its support. On the other hand, the long-term financial problems that started in the mid-1970s were also an important development for neoliberalism (Yaşar \& Uğurluoğlu, 2010). United States of America (USA) and in developed European countries such as the UK, "the reduction of budgetary shares has led to a general crisis in public health systems" (Güzelsarı, 2012).

Important steps have been taken to release the area created by this crisis to the free market. International Monetary Fund (IMF), With the support of International institutions such as the WB and the World Trade Organization (WTO), the privatization, governance, etc. of public spaces belonging to the state. It was thought to be created according to free market conditions with methods, and accordingly, the health service undertaken by the state was directly affected. In this context, the neoliberal policies implemented in the economy were realized with the health reforms that started in the 1980s and implemented in the 1990s
(Erol \& Özdemir, 2019). These health reforms, which were also realized with the effect of globalization, were implemented under the name of health policy with the support of institutions such as the IMF and (WB) in developing countries such as Turkey after a certain period of time. WB and IMF are the main actors in everything from the budget of the services provided by the health institutions depending on the health reforms (Erol \& Özdemir, 2019) became like that.

Globalization, one of the dimensions of neoliberalism (Savran, 1998), In its narrowest sense, it refers to the process of worldwide diffusion of capitalist policies (Çoban, 2015). One of the places where these policies are most effective today is the field of health. Globalization paves the way for countries to be involved in health policies through privatization, which is one of the dynamics of the free market. Thanks to privatization, which expresses the fulfillment of the operating and usage powers of the state by the free market, the state leaves the socio-economic field to the private sector and turns into a regulatory state for the operation and maintenance of capitalist production relations (Yaşar \& Uğurluoğlu, 2010). In this respect, privatization refers to the private sector's entry into the field of health services as financial resources and services (Belek \& Soyer, 1998). The most important application area today is the public-private partnership (Public-Private Partnership) model. Accordingly, according to the content of the project undertaken by the private sector, financial, infrastructure, repair and so on. is involved in one or more places (Uysal, 2019). Employment of personnel as civil servants in hospitals realized with Public Private Partnership and the evaluation of these personnel within the scope of this study were taken into consideration. However, since the situation that arises here will bring more costs for those who will benefit from health services (bed fee, examination fee, etc.) As a result, citizens' access to health services may also become problematic. For example, in the USA, the average life expectancy between the top $1 \%$ of the income distribution and the bottom $1 \%$ of the income distribution differs by 15 years for 40 -year-old men and 10 years for women (UNDP, 2019). According to the World Health Organization (WHO), "differences in life expectancy between men and women in low-income countries are due to causes that can be treated through access to primary health care. In addition, most of the factors affecting access to health services are outside the traditional mandate of health ministry's/state. It is emphasized that while the population in low-income countries generally has less access to basic health services, it is negatively affected by health expenditures even in high-income countries. (WHO, 2019). According to the World Bank, it has been stated that there are problems in middle-income countries in accessing health services in various countries. On the other hand, the continuous increase in individual health expenditures increased 
from $9.4 \%$ to $12.7 \%$ between 2000 and 2015 - showing the contrast between health expenditure and access to health (DB, 2019). In addition, it is stated that $10 \%$ of families' incomes went to health expenditures in 2015, and the percentage of the population that became impoverished due to out-of-pocket health expenditures increased from $1.8 \%$ in 2000 to $2.5 \%$ in 2015 (DB, 2019)

\section{Transformation of the Social State and the Marketing of the Health System}

The social state is the state that affects every aspect of social life with public means and makes this effect felt everywhere (Güler, 2006). The social state envisages the poor people in the society to have a more humane life and to join the society by eliminating their poverty (Bulut, 2003). However, towards the end of the 1970s, with the victory of the New Right, which accepted the neoliberal understanding economically, there was a change in the welfare state thought (Gönç, 2017). In the 1980s, deregulation and privatization policies, known as the abolition of the state's decision-making authority in the economy, and welfare state practices were replaced by neoliberal policies (Yaşar \& Uğurluoğlu, 2010). After 1980, with the effect of globalization, the process of liquidation of the welfare state accelerated.

In line with neo-liberal policies, practices towards shrinking the state in the field of health services have begun to be experienced (Doğan, 2017). With the shrinking of the state in the field of economy, imbalances have been experienced in many areas from income to health. According to 2018 World Inequality Report data, the share of wealth of the top $1 \%$ in the USA, which was $22 \%$ in 1980 , increased to $39 \%$ in 2014 , while the income shares of the bottom $50 \%$ increased to $20 \%$ in 1980 . decreased to $13 \%$ in 2016. On the other hand, it is seen that those who make up the richest $1 \%$ of the world have received twice as much growth since 1980 than the $50 \%$ that make up the bottom segment (World Inequality Report, 2018). With the abolition of the welfare state since the 1980s, neoliberal policies between continents also differ. Accordingly, while $1 \%$ of the population in Western Europe received $12 \%$ of the national income in 2016, this rate was $20 \%$ in the USA. In 1980, $1 \%$ of the population in Western Europe received $10 \%$ of the national income, while this rate was $11 \%$ in the USA. (World Inequality Report, 2018). Both public and private health expenditures are increasing around the world. $77 \%$ of health expenditures, which are over $\$ 7.7$ trillion, belong to developed countries. The average per capita health expenditure in the world is 1,061 dollars per year. In developing countries, the personal health expenditure of individuals is more than half a trillion dollars. In many countries, health services are provided through the private health sector, apart from the high fees allocated to health expenditures among the expenditures made by the states and the services they provide. Except for capitalist countries with free market conditions, health services in low- and middle-income countries are generally provided through private health institutions and aid organizations. Apart from this, with the factors brought by the development of technology in the last 40 years, significant improvements have been experienced in the field of health in the world and the quality of life of people has increased on a global scale. From 2000 to 2016, total life expectancy increased by 5.5 years, reaching the highest rate of the last 60 years, reaching 72.6 years. However, this positive picture is not always stable. Every year, individuals in developing countries pay more than half a trillion dollars for health, 930 million people allocate $10 \%$ of their household budget to health in 2015 alone, and increases in public or individual spending on health are not enough to provide financial protection. (https://insamer.com, e.t. 05.01.2021; World Health Statistics, 2020; WHO, 2019a; Www.Worldbank. Org, Https://Www.Worldbank.Org/En/Topic/Health/Overview\#4. 03.01.2021). In the WB and WHO 2019 joint report, it is stated that individual health expenditures between 2000 and 2015 contributed to the increase in global poverty, and it is predicted that 984 million people around the world will continue to pay for health by 2030. (WB and WHO Joint Report, 2019). In this regard, both state and individual budgets allocated to health expenditures increase inequality and poverty worldwide.

Despite the technological advances in the globalization process, state and individual-based expenditures in health expenditures are increasing. This situation shows the position of the individual and the state in the health system in line with the implemented neoliberal policies. However, it is necessary to examine the situation in terms of the other dimension of the work, namely health workers.

\section{The Effect of Neo-Liberalism on}

\section{Healthcare Professionals in a Globalized World}

Today, the role of the state in the field of health is reduced to the status of "observer" and the benefit of those who do not have financial income from the health sector is eliminated with health reforms. In this way, it is ensured that individuals are integrated into the free market by waiving the idea of benefiting from the health service provided to them by the state through reforms. Thanks to the "reforms" that transform the health services offered by the states into health services based on the neoliberal free market understanding, the health services provided are privatized (Gönç, 2017). In other words, states try to save money by reducing health expenditures, but on the other hand, the segment in which health services are provided has also narrowed. 
WHO recognizes the need for health reform (2008), summarized in four points? These; universal inclusiveness of health systems towards (i) health equity, (ii) social justice (iii) ending exclusion; service delivery to make health care more social around people's needs and expectations; (iv) public policy making to integrate public health actions with primary health care and pursue sound public policies across sectors, and finally the inclusive, participatory, deliberative leadership required by leadership reform. The starting point of these reforms is to reduce inequalities and facilitate access to health. In addition, it is a reconsideration of health in terms of health workers. However, the reforms increase inequality even more and have negative aspects on health workers. In this context, as a result of the implemented neoliberal policies, the business logic in hospitals is developing. Due to the increase in the number of patients, the number of health workers remains insufficient. More workload is put on healthcare professionals and the patient-physician relationship may deteriorate due to the intensity. Secondly, states are making changes in the understanding of civil servants within the framework of health reforms, and it is aimed to provide services to health workers according to the contract procedure. In this respect, the way for subcontracting in health is also paved. Third, with the performance system application, doctors are paid according to the number of patients they see and the unit they work in. With this understanding, a number-based mechanical system is created for healthcare professionals (especially doctors), away from humane working conditions. Especially with the Covid-19 epidemic that started in the world in 2019, healthcare professionals are expected to show superhuman performance.

\section{The Transformation of the Health System} in Turkey due to Globalization: Transition to Market Economy Through

\section{Neoliberalism Policies and Health Reforms}

The 1980s are important in the transition to neoliberal policies in Turkey. One of the most important indicators in the transition is the decisions taken on January 24, 1980. These decisions highlight the free market economy. The active role of the state in providing health services has been reduced and financial resources have been cut and the state has moved away from its primary duty in the field of health, as in many areas, and left its place to the free market(Pala, 2007). The most concrete expression of this is in the 1982 Constitution. Accordingly, the health services that the state is obliged to fulfill have been rearranged in accordance with neoliberal policies. In this context, the state has undertaken the role of controlling health institutions by cooperating with the private sector(1982 Anayasas1, md.56). Another important development of the 1980s was the regulation of health services according to the free market understanding with the Health Services Basic Law No. 3359 in 1987(Yaşar \& Uğurluoğlu, 2010). According to the 3rd article of the relevant law, health services are opened to commercialization by determining the prices related to the services provided in state-owned health institutions and businesses by the Ministry of Health (Erol \& Özdemir, 2019). With the article added to the same law, health services are made to be bought and sold with the employment of contracted personnel(Turancı ve Bulut, 2016; 3359, Geçici md.1). The Health Reform, which started in the 1980s with neoliberal policies, was replaced by a new understanding in the early $2000 \mathrm{~s}$ with the "Health Transformation Program (Session Description Protocol)" announced in 2003. Accordingly, the Ministry was brought to the level of planning and supervision, health institutions were transformed into health enterprises in the understanding of administrative and financial autonomy, and it was aimed to make health services effective and efficient(Sağllk Bakanlığ1, 2003). With the gathering of health services under one roof with General Health Insurance (General Health Insurance), the transition from health centers to family medicine -in 2010, the transition to family medicine was completed in Turkey- a market-based service approach was adopted in the operating logic of public hospitals(Erol \& Özdemir, 2019; Pala, 2007; Bakar, 2014). With the General Health Insurance, the necessary financing of the state is provided.All citizens are covered by the General Health Insurance and are required to pay their compulsory health insurance shares.Citizens who do not pay their insurance shares, on the other hand, are cut off from health services, but can receive this service for a fee(Balta, 2013; Pala, 2007). While the monthly amount required to be paid by the citizens who want to benefit from the UHI, which has been made compulsory since January 2012, was 88.29 TL, this amount has been increased to $107.32 \mathrm{TL}$ as of January 2021(http:/Www.sgk.gov.tr, e.t. 28.01.2021). With the Green Card Law dated 18.06.1992 and numbered 3816, the treatment expenses of the citizens who cannot afford to pay are covered by the State by issuing a Green Card( http://www.mutki.gov.tr/yesil-kart-islemleri).

In Turkey, the number of green card holders given to those who are unable to receive health care due to lack of financial means to benefit from health services has exceeded 8 million(https://t24.com.tr/haber/yesil-kart-li-vatandas-sayisi-8milyon-628-bine-ulasti,). When the literature is examined, it can be seen that researchers cannot agree on the service logic in the field of health in Turkey. Some researchers argue that the market logic is established in Turkey, especially in the health sector(Örneğin; Aksoy, 2007, Koç ve Vurgun, 2012, Özseven vd., 2014). However, it is seen that some researchers argue that 
the mechanisms prescribed by the market logic do not work in the health sector (For example, Meydan et al. 2020). According to the Health Expenditure Statistics 2019 report published by the Turkish Statistical Institute (TÜiK) on November 19, 2020, the total health expenditure in 2019 increased by approximately $22 \%$ compared to the previous year and reached approximately 201 billion dollars, which resulted in an approximately $23 \%$ increase in government health expenditures and It has been shared that the private sector consists of a combination of approximately $19 \%$ increase in health expenditure. In addition to this data provided by the Turkish Statistical Institute, it has been estimated that the general government health expenditure amount for 2019 was approximately 157 billion dollars and the private sector's health expenditure was 44 billion dollars (https://data.tuik.gov.tr/Bulten/Index?p=Saglik-HarcamalariIstatistikleri-2019).

The next publication date of these statistics is stated by the Turkish Statistical Institute as December 2021. Due to the Covid-19 pandemic, which was more successful than other countries in the beginning, but felt the effects in 2020, a higher rate of increase is expected in health expenditures in 2020. The change in health expenditures in Turkey between 2010 and 2019 is shown in Figure 1 below.

Figure 1. Health Expenditures, 2010-2019 (Total, General Government and Private Sector) (Bilion TL)

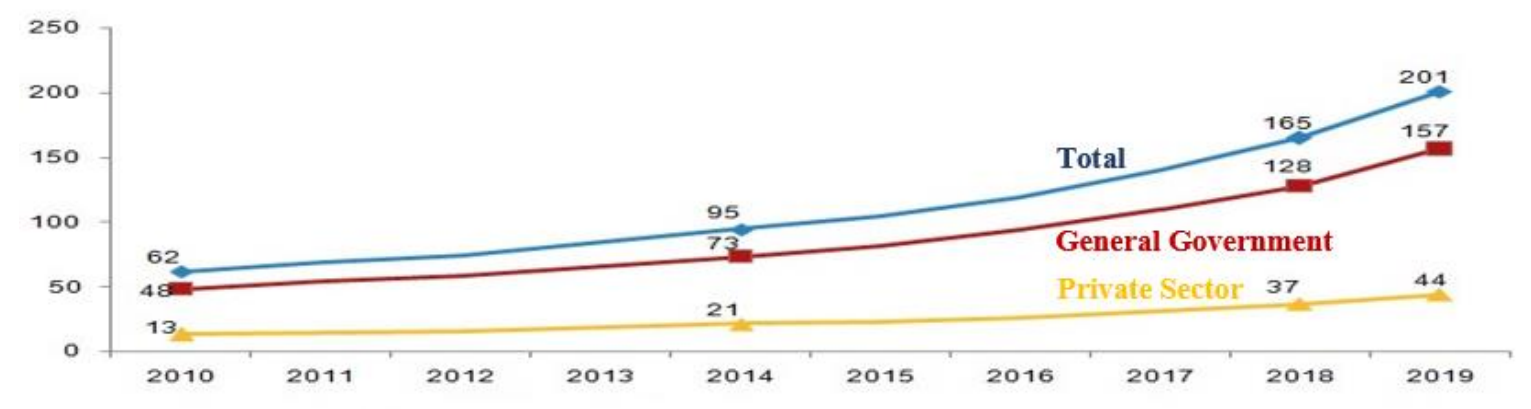

Source: Health Expenditure Statistics, 2019 (https://data.tuik.gov.

tr/Bulten/Index?p=Saglik- Spending-Statistics-2019).

With the Decree-Law dated 3 November 2011 and numbered 663 (Decree Law), a change and transformation was made in the structure of the Ministry of Health and its affiliated organizations. With this Decree, the transition from management to governance was ensured by the establishment of the Turkish Medicines and Medical Devices Agency with a special budget, and the Public Hospitals Institution of Turkey and the Public Health Institution of Turkey, which were based on decentralization instead of centralization, and certain staff to be employed on a contract basis (Balta, 2013; Erol \& Özdemir, 2018). With this change in 2011, instead of performing public health services directly, businessbased management was initiated through the Public Hospitals Association. In this context, each union has been accepted as a performance-based system with its own contracted personnel. While the share of health in the general budget decreased as neoliberal policies became operational in health, the share of other resources was increased with interventions such as General Health Insurance, and the period of paid treatment in the public began, thus creating a performance-based structure (663 KHK md. 29/2; Aktel et.al., 2013; Pala, 2016). As of 2014, the contribution fees previously received only from drugs, it has started to be popularized in many areas such as medical examination, additional fee per drug, early examination, private hospital (Bakar, 2014).

\section{Legal Rights of Physicians in Turkey}

A physician is a person who works for human health, does his/her job within the framework of the legal rights granted to him by the state, and intervenes medically on behalf of the society and human health due to his duty. From this point of view, we can say that the profession of medicine has a priority in protecting human and public health. Healthcare professionals, physicians, fight the epidemic in the forefront of their work and put their own health in the second place against patients. The legal rights of physicians in Turkey are enshrined in the Constitution, the Law on the Practice of Medical Sciences, the Law on the Turkish Medical Association, the Regulation on Medical Deontology, the Regulation on Treatment Services, and the Law No. 657 on Civil Servants.However, today, when we look at the content of these laws, deficiencies in the legal rights of physicians are obvious (Yalçın, 2011).

With a regulation made in 1998, the rights of patients against physicians were expanded and the number of lawsuits filed against physicians increased significantly (Tanrıverdi vd., 2014). 
Today, this tendency to violence has become controversial again with the epidemic.

If we briefly touch on the rights of physicians in the law; The right to refuse the patient and not to leave the patient unless another colleague arrives (Tıbbi Deontoloji Tüzüğü md.18 ve 19), “The right not to touch one's bodily integrity" (Constitution art. 17) and the Turkish Medical Association's "Turkish Medical Association .It was updated in the 58th Grand Congress of the Ethical Declarations Workshop and was rearranged in 2018 depending on the years, and in November 2019, the Turkish Medical Association Extraordinary. On the other hand, in the Declaration of the Rights of the Physician (Turkish Medical Association) adopted in the Grand Congress, there is the right to benefit from and demand many rights such as using leave, ensuring occupational safety, minimizing occupational risks, ensuring the safety of life and property from the state, and demanding personal rights (TTB, 2019).

\section{Effects of Covid-19 on Physicians}

The Covid-19 epidemic, which started towards the end of 2019 and still continues in the world, has caused and is causing significant problems in Turkey as well as in the world. Apart from human losses, the epidemic brought many health problems such as runny nose, back pain, breathing difficulties, taste and smell. From March 11, 2020, when the first case was seen in Turkey, until January 29, 2021, when this article was written, the total number of cases in Turkey was 2,464,030, the number of deaths was 25,736 and the number of patients was 1740(http://www.covid19.saglik.gov.tr, e.t 29.01.2021). 30 thousand health workers were affected by the epidemic, 302 of them died.117 of those who lost their lives were physicians(Https://Www.Yenicaggazetesi.Com.Tr/Korona29.12.2020)

The epidemic has significant effects on healthcare workers. One of these effects is the difficulties experienced in coping with stress in one of every 6 health workers during the epidemic(Bozkurt vd., 2020). In Turkey, health workers are faced with problems such as not resigning by the state, not retiring, leave cancellations or unfair and uncertain work(Saatçi, 2020). Violence and communication with patients' relatives are among the other effects.In the later stages of the epidemic, images of patients or their relatives that reach the level of violence against healthcare professionals, especially physicians working in the emergency, emerge. This situation for physicians trying to do their duty brings the issue of life safety to the forefront for physicians. Another dimension of the epidemic for physicians is that Covid is not considered as an occupational disease by the state. In addition, in case of death due to the epidemic, physicians who died cannot receive compensation because it is not considered an occupational disease.Therefore, physicians may fall into victim status due to both being under high risk and the possibility of losing their rights in terms of personnel.The loss of colleagues, communication problems with patients, the complete cessation of their social life, the decrease in their contact with their families, the fact that they spend most of the day at work due to overwork, the inadequacy of improvements in additional wages, the direct reflection of every measure taken by the state on their working life can prevent physicians from working in a healthy environment. and may cause them to not be able to fully manage the crisis.

\section{Istanbul Chapa(Çapa) Hospital Interview With Physicians Fightong Covid-19}

Istanbul Chapa Hospital, which has an important place in the fight against the epidemic, was chosen as the application area in the study. The first doctor's death due to Covid, internal medicine doctor Prof. Dr. Cemil Taşçığlu, being the hospital where he took place and being one of the most important hospitals in Turkey, has been effective in the selection of this hospital. Qualitative research method was used in the study. In Turkey, legal and administrative data on the rights of healthcare personnel have been examined. Then, the data obtained from the doctors providing health services in Istanbul Çapa Hospital were transferred as they were in the study, without touching the essence. Ratios and percentages were made according to the mathematical percentage method. At Chapa Hospital, physicians from two departments were interviewed; (i) Chest portion; 4 foreign nationals and 12 locals in this section, (ii) Internal Medicine section: 10 foreign nationals and 58 people are considered local in this section. First-hand data were collected through one-on-one interviews with 11 physicians who were in charge of these physicians, and the random method was applied.

A total of 6 previously prepared questions were asked to them, and the question of whether to answer the questions was left to the participants. Of the 11 participants who participated in the interview, 6 were female and 5 were male. 4 of the participants are foreign nationals. The average duration of the interviews with the participants is 40 minutes. In the study, separate interviews were conducted with the participants in order not to be influenced by each other. The 6 questions asked to the participants $(F)$ in the study are as follows:

1- Do you think Covid-19 has affected your working life?

2- Do you think that the hygiene conditions are sufficient in the fight against Covid-19 in your institution?

3- Do you think the legal rights in your working life are sufficient? 
4- Do You Have Problems in Communication with Covid-19 Patients?

5- According to you, are the methods of coping with Covid-19 effective?

6- Are you satisfied with your personal rights in the hospital where you work?

In the interviews, all of the participants stated that the Covid-19 epidemic affected their working life to the first question. In addition, all of the participants to this question stated that working hours and life risks have increased, working styles have changed, returning to the shift system, long shifts, etc. K1 said that the epidemic affected their working life, losing their colleagues, seeing patients of the same type, and the fact that the epidemic became wearisome over time affected him and his colleagues psychologically, and added that, unlike $\mathrm{k} 4$ and $\mathrm{k} 8$, the stress environment increased in the hospital.

To the second question, six of the participants said that the hygiene conditions were "adequate", and five of them $(\mathrm{K} 1, \mathrm{k} 5$, K7, K10 and K11) said they were partially sufficient. The common point of the participants who said that this question was both sufficient and partially sufficient is that they said that there was no shortage of masks, equipment and cleaning materials. However, K1 is the only woman to say that the building they work in is old and that there is no negative pressure room.

To the third question, 9 of the participants said that legal rights were insufficient, k6 said that they had no complete idea about this, and P8 said that there was no negativity other than the material issue. $\mathrm{k} 9$, who finds their legal rights insufficient, stated that they can get an additional fee for up to 7 shifts if they keep watch, they cannot get additional pay for 7 shifts, they are considered on duty after the shift and they work up to 35-36 hours. K10, on the other hand, said that there are still inadequacies in the punishment of violence to the doctor, apart from the material issue. K3 states that on legal rights, Covid is not considered an occupational disease and there is no legal regulation for it, improvements in the balance of payments are not considered sufficient, wages are low compared to the risk taken,

K1 states that there are bureaucratic difficulties. K2 states that Covid is not considered an occupational disease.

Participants gave different answers to the fourth question. K1, k7, $\mathrm{k} 8$, K9 and k11 stated that there were more problems in communicating with patients at the beginning of the epidemic, but their communication problems with the patient decreased due to the prolongation of the epidemic.k4 and k10 stated that communication problem was experienced and continued. K10 stated that the reason for this was different expectations. The rest of the participants stated that they did not experience communication problems. Of these, K5 stated that there were no problems with those who were hospitalized due to Covid, but they could not agree because the attitudes of the patients who came to the were not normal.

To the fifth question, 4 of the participants indicated that the methods were insufficient and that the effects of the K10 and K11 methods could not be known, as a justification for a new epidemic type and being unique from the previous ones. $\mathrm{K} 6$ and $\mathrm{K} 8$ said that the methods were effective, K3 and K6 said that the methods could be more effective, and K9 said that the methods were sufficient at first.Among those who say that the method is insufficient, K5 thinks that the methods are loosened at some points.K8, who argued that the methods were effective, said that the number of people who applied to the hospital at first was around 1200, but thanks to the methods, this number has decreased to 150 in recent years.

For the sixth question, only P8 thinks that their personal rights are sufficient and they are foreign nationals. K10, who is a foreign national, says that they do not have much information about personal rights. All of the remaining participants said that they were not satisfied with their personal rights and that their personal rights were weak. The most interesting answer to this question was given by K5. According to him, he thinks that health workers are unfairly treated by the media about being overpaid, and that they do not receive a monetary and moral reward. K3 does not think that every written right is provided. K4 expressed his opinion that adequate laws on personal rights should be enacted and cooperation with professional organizations should be established.

\section{Conclusions}

The Covid-19 pandemic causes the number of healthcare workers who died due to Covid-19 to increase day by day in the world. Working in unhealthy conditions, being exposed to violence by patients or their relatives, working with inadequate and unhealthy tools, increase in working hours, and finally, in some countries, such as Turkey, due to their professional rights and personal rights (not being able to resign, not being able to retire, not considering Covid as an occupational disease). etc.) problems are reflected negatively on health workers. In general, according to the findings obtained in the research; There is a consensus on some points such as Covid-19 is not considered an occupational disease and no legal action has been taken on this issue, the issue of wages should be reconsidered, working under stress and intensively is not efficient, wages received with working conditions are incompatible, the risk is higher than other epidemics. have been found to provide. Out of consensus, some 
participants, like K5, think that the media exaggerate the issue of wages for healthcare workers. They stated that they experienced fear and anxiety at the beginning of the epidemic. They considered the non-compliance of the measures taken by people as the reason for the odor and anxiety they experienced. In addition, foreign national physicians have opinions that there is no injustice in wages and that their personal rights should be better. The point that draws attention in the interviews is that female physicians tend to answer questions more than males. Positively, physicians think that the hospital has taken the necessary precautions for them regarding hygiene.

\section{References}

1. Aksoy, B. (2007), “The Role of a Professional Association in Institutional Change: The case of Turkish Health Field" Unpublished Doctoral Thesis. Baskent University, Institute of Social Sciences, Ankara. Available at http://acikerisim.baskent.edu.tr/handle/11727/2132

2. Aktel, M., Altan, Y., Kerman, U., \& Eke, E. (2013). Transformation of Health Policies in Turkey: An Analysis on the Provincial Organization of the Ministry of Health. Afyon Kocatepe University Journal of Social Sciences, 15(2). Available at https://web.a.ebscohost.com/ehost/pdfviewer/pdfvie wer?vid=0\&sid=a4c753b3-f75a-4cb6-85cfba710ea9f485\%40sessionmgr4008

3. Ataay, C. K. (2016). Hayek and Friedman's understanding of the state. Marmara University Journal of Political Sciences, 4(1), 129-151.

Available at https://dergipark.org.tr/en/pub/marusbd/issue/17219/ 179861

4. BAKAR, C. (2014). The Utopia of the Twentieth Century: Reform for All! Equality for all (you)! Society and Physician, 29(1), 61-80. Available at https://app.trdizin.gov.tr/makale/TVRVM09URXINZ z09/yirminci-yuzyilin-utopyasi-herkes-icin-reformherkes-icin-esit-siz-lik-

5. Balta, E. (2013), "From Health for All to Health as Much as Money: Neoliberal Transformation of Health Policies in Turkey", 147-166. Available at https://app.trdizin.gov.tr/publication/paper/detail/TV $\underline{\text { RRMU1qQX1NZz09 }}$

6. Bozkurt, A., Karakoç, B., Sonmez, E., et al. (2021). "Recommendations to Health Institution Managers for the Protection of Mental Health of Healthcare Professionals" e.t.25.01.2021. Available at https://dergipark.org.tr/tr/pub/egifder/issue/7469/98353
7. Bulut, N. (2003). Globalization: The End of the Social State? Journal of Ankara University Faculty of Law, 52(2). Available at https://dergipark.org.tr/en/download/articlefile/628985

8. Choban, S. (2015). Küreselleşme Sürecinde Gelişmekte Olan Ekonomilerde Sağlık Harcamalarının Finansmanı (Yüksek Lisans Tezi). Available at

https://atif.sobiad.com/index.jsp?modul=makale$\underline{\text { detay } \& A l a n=\text { sosyal } \& I d=A W 6 P n n x L y Z g e u u w f e Z f D}$

9. Doğan, B. Ş. (2017). Customızıng Health Services in Turkey: The Project of Transformation In Health. Available at https://www.Researchgate.Net/Profile/Bilge-Senturk2/Publication/330764222_Anahtar_Kelimeler_Saglik ta_Donusum_Projesi_Turkiye_Neoliberalizm/Links/ 5c53314092851c22a39e4781/Anahtar-KelimelerSaglikta-Doenuesuem-Projesi-TuerkiyeNeoliberalizm.Pdf

10. Erol, H., Özdemir, A. (2019) "Transformation of Health Policies After 1980 and Its Effects on Health Expenditures in Turkey." International Journal of Management, Economics and Business 15. (15), 119146.

https://doi.org/10.17130/ijmeb.2019CEEIK20185410 2

11. Guler, B. A. (2006). Social State and Localization. Homeland Politics Management, 2, 29-43. Available at http://www.yayed.org

12. Gunaydin, D. (2012). Global Reform Approaches in Healthcare. Journal of Social Politics Conferences, (60), 323-365. Available at https://web.b.ebscohost.com/

13. Guzelsari, S. (2012). Restructuring and PublicPrivate Partnerships in the Health System. Journal of Public Administration, 45(3), 29-57. Available at https://ses.org.tr/wp-content/uploads/

14. July, G. O. N.C. (2017). The Impact of Neoliberal Policies on Health at the Global Level. Anadolu University Journal of Social Sciences, 17(1), 159178. Available at https://dergipark.org.tr/en/pub/ausbd/article/415673

15. Kayan, A. (2015). An evaluation of the effects of globalization on cities and the characteristics of global cities. Available at http://acikerisim.lib.comu.edu.tr:8080/xmlui/handle/ COMU/1337

16. Koçak, H. (2009). Local Democracy and Urban Life in the Age of Globalization and Localization. 
Suleyman Demirel University Journal of Social Sciences Institute, (10), 133-142. Available at https://dergipark.org.tr/

17. Oktay, K. O. C., \& Vurgun, L. (2012). Managing the rivalry of antithetic Institutional Logics: a qualitative study in the scope of Turkish healthcare field.

Journal of Economic and Social Studies. Available at https://dergipark.org.tr/

18. Özseven, M., Consultant, A. and Bingöl, A., (2014). Transformation or Development? Towards a New Institutional Logic in the Management of Public Hospitals. METU Development: 119-150. Available at https://open.metu.edu.tr/bi

19. Pala, K. (2007). What Kind of Health Reform for Turkey? pp.3-42. Available at https://d1wqtxts1xzle7.cloudfront.net/32759111/sagli k_reformu

20. Pala, K. (2016). Health Reform Health Transformation Program Process in Turkey. Meat, 25, 2020. Available at https://www.researchgate.net/

21. Saatçi, E. (2020). The Covid-19 Pandemic and Healthcare Workers: To Live or to Live? Turkish Journal of Family Medicine. 24(3): 153-166. Available at https://jag.journalagent.com/

22. Sağlık Bakanlığı, Sağlık 2003. Available at https://dosyasb.saglik.gov.tr/Eklenti/5153,2003raport rpdf.pdf?0

23. Savran, S. (1998). New World Order (Sizliğ), Globalization, Privatization. New World Order and Privatizations. Turkish Medical Association, Ankara. Available at https://www.ttb.org.tr/k

24. Soyer, A., \& Belek, I. (1998). Private health sector and privatization in health in Turkey. Society and Physician, 13(1), 35-45. Available at https://www.belgelik.dr.tr/

25. Tanriverdi H. (2014). Physician Rights in terms of Medical Ethics, Beu. sbe. Journal, Vol:3, Issue: 1 June 2014 https://dergipark.org.tr/e

26. Tibbi Deontoloji Nizamnamesi, Available at https://www.mevzuat.gov.tr/MevzuatMetin/2.3.4125 78.pdf

27. TTB Hekim Hakları Bildirgesi 2019 Kasım. https://www.ttb.org.tr/kutuphane/etikbildirgeler.

28. Turanci, E., \& Bulut, S. (2016). Neo-Liberalism and the Transformation of Healthcare: An Analysis of the Communication Policies of the Private Health Sector. Journal of Communication Theory and Research, (43). Available at https://iletisimdergisi.hacibayram.edu.tr/
29. UNDP, Human Development Report 2019, Available at http://hdr.undp.org

30. Uysal, Y. (2019). Public-Private Partnership (BuildLease-Transfer) Model and Effects of City Hospitals on Change and Transformation in Health Services. Eskişehir Osmangazi University Journal of Economics and Administrative Sciences, 14(3), 877898. Available at https://dergipark.org.tr/

31. WHO, (2020). "World Health Statistics, A Visual Summary", Https://Www.Who.Int/Data/Gho/Whs2020-Visual-Summary.

32. WHO. (2008). World Health Report. Primary Health Care Now More Than Ever, Switzerland, 2008.

33. WHO, (2019). World Health Statistics Overview.

34. World Bank, Global Monitoring Report On Financial Protection in Health, 2019.

35. World Health Organization. (2019). Primary Health Care On the Road to Universal Health Coverage: 2019 Monitoring Report: Executive Summary (No. Who/His/Hgf/19.1). World Health Organization.

36. World Health Organization. (2020). Global Monitoring Report On Financial Protection İn Health 2019. Available at

Https://Apps.Who.İnt/İris/Bitstream/Handle/10665/3 31748/9789240003958Eng.Pdf?Sequence $=1 \&$ İsallowed $=Y$

37. World Inequality Report. (2018). Available at https://wir2018.wid.world/files/download/wir2018summary-turkish.

38. Yalcin, S. (2011). Laws and Regulations Regarding Surgeons., pp.37-44. https://www.journalagent.com/

39. Yeniçağ, (2020). You Won't Believe the Number of Health Care Professionals Died in Turkey from Corona Virus, 29.12.2020. Available at https://www.yenicaggazetesi.com.tr/

40. Yenimahalleli Yaşar, G., and Uğurluoğlu, E. (2010). "Neoliberalism, Globalization and Health." Ankara University Dikimevi Health Services Vocational School Journal 9.1, 1-10. https://dergipark.org.tr/en

41. 12-Ordinance No. 663 on the Organization and Duties of the Ministry of Health and Affiliates, 2 November 2011. Available at https://www.resmigazete.gov.tr/eskiler/2011/11/2011 1102M1-3.htm

42. 1982 T.C. Anayasası, Available at https://www.anayasa.gen.tr/1982ay.htm

43. 3359 Sayılı Sağlık Hizmetleri Temel Yasası, https://www.mevzuat.gov.tr/MevzuatMetin/1.5.3359. pdf

44. http://www.mutki.gov.tr/yesil-kart-islemleri 
45. http://Www.Sgk.Gov.Tr/Wps/Portal/Sgk/Tr/Calisan/ Gss_Tescil_Sureci/Gss_Hangi_Tarihten

46. http://www.sgk.gov.tr/wps/portal/sgk/tr/kurumsal/me rkezteskilati/yardimci_hizmet_birimleri/insan_kayna klari_daire_baskanligi E.T. 28.01.2021

47. https://data.tuik.gov.tr/Bulten/Index?p=SaglikHarcamalari-Istatistikleri-2019-33659

48. https://Insamer.Com/Tr/Kuresel-Saglik-Sistemi-VeAdaletsizlik 3361.Html E.T 05.01.2021

49. https://t24.com.tr/haber/yesil-kart-li-vatandas-sayisi8-milyon-628-bine-ulasti,840695

50. https://www.psikiyatri.org.tr/uploadFiles/303202011 5022-SaglikKurumlariCOVID.pdf

51. https://Www.Resmigazete.Gov.Tr/Eskiler/2011/11/2 0111102m1-3.Htm

52. https://www.takvim.com.tr/guncelon-dakika-saglikbakanligi-koronavirus-vaka-sayilarini-duyurduguncel-covid-19 E.T 29.01.2021

53. https://Www.Ttb.Org.Tr/Makale_Goster.Php?Guid= 484cccb8-9041-11ea-9b7d-6d38d16eb233

54. https://Www.Yenicaggazetesi.Com.Tr/KoronaVirusten-Turkiyede-Olen-Saglikci-Sayisinaİnanamayacaksiniz-Rakamlar-Korku-Sa324955h.Htm

55. https://Www.Worldbank.Org/En/Topic/Health/Overv iew\#4 E.T. 03.01.2021 